\title{
PREPARATION AND EVALUATION OF DIFFERENT NUTRITIVE FORMULAS FOR CHILDREN (AGE 1- 3 YEARS)
}

\author{
DEWIDAR, OMAIMA M. ${ }^{1}$, AYAT E. RIZK²and M. H. AHMED ${ }^{3}$
}

1. Department of Crops Technology Research, Food Technology Research Institute,

2. Department of Special food and nutrition. Food Technology Research Institute, ARC, Giza, Egypt.

3. Ain Shams University Hospitals

(Manuscript received 3 May 2017)

\begin{abstract}
$\mathrm{T}$ hree composite formulas for children (age 1-3 years) were prepared from boiled rice, wheat, corn, lupine chickpea and cowpea to improve protein quality. The quality was evaluated by determining the proximate chemical composition, physical properties, microbiological and sensory characteristics. Vegetables (sweet potato and carrots), fruits (mango and dates) were also used in three composite formulas. The formula (2) had the highest protein content $(22.89 \%)$, while formula (3) had the highest fat and fiber content $(2.0,7.7 \%$, respectively). On the other hand formula (2) had the highest protein digestibility (93.62 $\%)$. Formula (1), also had the highest Fe content $(10.9 \mathrm{mg} / 100 \mathrm{~g})$. While formula 3 had the highest, $P$ content $(455 \mathrm{mg} / 100 \mathrm{~g}$ ) compared with the formula 2 which had the highest $\mathrm{Ca}$ and $\mathrm{Zn}$ ( 325.5 and $8.0 \mathrm{mg} / 100 \mathrm{~g}$, respectively). After storage for 15 days at $4{ }^{\circ} \mathrm{C}$ the formula (2) showed a minimal total count growth of TBC and Yeast \& molud $\left(2 \times 10^{3}\right)$. While mold and yeast growth were not detected in any formula. Sensory evaluation indicated that there were significant differences $(p<0.05)$ among the three composite formulas in texture, taste and overall acceptability before and after storage and the formula (1) was the best. Since the prepared formulas are free from artificial colors and preservatives, they are safe, healthy and nutritious for the child to grow in a good health and recover from malnutrition. Therefore, the current study, concluded that these products could be manufactured at home scale as well as on the commercial scale for children.
\end{abstract}

Key words: children, feeding, formulas, protein digestibility, nutritious.

\section{INTRODUCTION}

Good nutrition is an essential part of healthy children. It is essential for the growth and development that occurs during an infant's first year of life. Child's early years, which are important for their future health and wellbeing and good nutrition during this time, lays a healthy foundation for all of childhood and of life (D'Souza. 2013). Nutrition is the cornerstone of socioeconomic development of a country. It is an essential component of millennium development goals and primary health care. 
Malnutrition, especially in children, is a common disease in less-developed countries mostly due to inadequate food intake. About 5 million children have died worldwide directly or indirectly due to malnutrition and 9 children/minute die as a consequence of malnutrition.

In Egypt, the Demographic Health Survey 2008 revealed that about 17.6\% of children under five years are stunted and about 4\% are wasted (El-Mougi, 2016). Optimal nutrition has great important effects during the first years of life than during any other period because of its effect on brain growth, the development of the nervous system, overall growth, development and future health practices. The first two years of life is a time of great change or in the child nutrition, from a diet consisting entirely of milk (breast milk and/or infant formula) to one consisting of a variety of foods. (Tarzi et al., 2012).

Cereal food products are an important part of the human diet with wheat being the most commonly consumed cereal in many parts of the world. Legumes contain considerable amounts of anti-nutrients which reduce mineral bioavailability and interfere with digestion of specific compounds. Soaking is one of the simplest processes used to reduce anti-nutrient content and increase bioavailability of minerals. Mixing grains with legumes leads to integration of the essential amino acids, which raises biological value, since legumes are good sources of lysine and total protein, while cereals represent superior sources of sulfur amino acids- (Aleid,S.M., 2016).

Date fruits are rich source of carbohydrates, most of which are in the form of simple sugars. The consumption of $100 \mathrm{~g}$ of dates provides over $15 \%$ of the daily Recommended Dietary Allowance (RDA) to Adequate Intakes (AI) of selenium, copper, potassium, and magnesium (Al-Farsi and Lee, 2008). Mango fruit is one of the most popular and nutritionally rich fruits with unique flavor, taste, and heath promoting qualities, making it functional foods (Kittiphoom 2012). Carrot has been traditionally considered an important dietary source of $\beta$-carotene and good source of fiber. (Al-Farsi and Lee, 2008)

The aim of the present work is to formulate and prepare supplementary food of low price which may help as nutritional support for children (1-3 years) from crops and fruits locally available, to solve the problem of malnutrition in children and improve the health status and nutrition.

\section{MATERIALS AND METHODS}

\section{Materials:}

The raw materials used for preparing different formulas included: - 


\section{1-Cereals and legumes}

-Rice (Giza 178), wheat (Giza 91), maize (Giza151), dry cowpeas (Dokke 331), chickpeas (Giza 195), lentils (Giza 2) and lupine (Giza 1) were obtained from Field Crops Research Institute, ARC, Giza, Egypt.

\section{2- Fruits and vegetables}

Dates, Carrot, Mango and Sweet Potato were purchased from local market in Dokke, Giza Governorate.

\section{3- Skimmed milk powder}

Skimmed milk powder used to prepare the different formulas was purchased from local market at Giza Governorate.

\section{Methods:}

Formulation and processing were done under ambient laboratory conditions. Rice grains were cooked for $25 \mathrm{~min}$, Lentils and lupin were blanched at $80^{\circ} \mathrm{C}$ for $30 \mathrm{~min}$. Sweet potato and carrot were blanched by steam until become soft. All ingredients were mixed using multi Moulintt Mixer (Moulinex,France). All the formulas were packed in sterilized jar and stored in the refrigerator at $4^{\circ} \mathrm{C}$ for 15 days. The ingredients of each formulas are shown in Table (1).

Table 1. Ingredients of the different formulas diets

\begin{tabular}{|l|c|c|c|}
\hline Ingredients & Formulae 1 & Formulae 2 & Formulae 3 \\
\hline Rice $(\mathrm{g})$ & 30 & - & - \\
\hline Wheat $(\mathrm{g})$ & - & - & - \\
\hline Corn $(\mathrm{g})$ & - & - & 30 \\
\hline Cowpeas $(\mathrm{g})$ & 20 & 20 & - \\
\hline Lentil $(\mathrm{g})$ & - & 30 & - \\
\hline Lupine $(\mathrm{g})$ & - & - & 30 \\
\hline Chickpea $(\mathrm{g})$ & - & 10 & 10 \\
\hline Date $(\mathrm{g})$ & 10 & 10 & 10 \\
\hline Mango $(\mathrm{g})$ & 10 & - & 10 \\
\hline Carrot $(\mathrm{g})$ & - & - & - \\
\hline Sweet potato (g) & 20 & 10 & 10 \\
\hline Skimmed milk powder $(\mathrm{g})$ & 10 & 100 & \\
\hline Total $(\mathrm{g})$ & 100 & & 100 \\
\hline
\end{tabular}

\section{Physical properties of prepared formulas.}

$\mathrm{pH}$ of each fresh formula sample was determined by using Digital $\mathrm{pH}$ - meter (Wen way, model 3020 Dunnou, Essey, UK) at room temperature. Water activity aW was measured with a Rotronic Hygro LapEAIO.SCS Switzerland ${ }^{a} \mathrm{~W}$ meter and the measurements were performed in triplicate. Viscosity (CP) measurement was carried 
out by the Brookfield Digital Viscometer Model DV-II+ A. temperature-controlled water bath was used to regulate the temperature of the samples according to Pastor et al., (1996).

\section{Chemical analysis}

\section{Chemical analysis of prepared formulas}

Moisture, protein, crude fiber, fat, ash contents and minerals ( $\mathrm{Fe}, \mathrm{Ca}, \mathrm{P}$ and $\mathrm{Zn}$ ) of the prepared formulas were determined according to the method described in AOAC (2012).Total carbohydrate were calculated by difference. Total calories were calculated as mentioned by Kerolles (1986) according to the following equation

Total calories $=4$ (protein + Carbohydrates $)+9$ (fat) .

\section{Bioavailability of minerals in formulas.}

The bioavailability of iron, zinc and calcium were determined by in vitro digestion method as described by Kiers et al., (2000).

\section{Determination of amino acids in formulas.}

Determinations of amino acids were determined according to the method described in AOAC (2012) by using High Performance Amino Acid Analyzer . Chemical Score was calculated according to FAO (1991).

C.S $=\quad$ mg of essential amino acid in g test protein $\mathrm{mg}$ of essential amino acid in requirement pattern

Protein Efficiency Ratio (PER) was calculated using the equation suggested by Alsmeyer et al., (1974).PER = - 0.684+0.456 Leucine - 0.047 Proline $(\mathrm{g} / 100 \mathrm{~g}$ protein)

Biological Value (B.V) was calculated according to equation of Oser (1959).

B. $V=49.9+10.53$ PER

Determination of in vitro protein digestibility .In vitro protein digestibility was determined according to the method of Akeson and Stahmann (1986).

\section{Sensory evaluation.}

Three fresh formulas were sensory evaluated at zero time and after 15 day of storage in the refrigerator at $4 \pm 1^{\circ} \mathrm{C}$ according to the Metwalli et al., (2011) by ten well trained panelists from the staff members of Food Technology Research Institute at ARC. The scoring scheme was established for color, texture, taste, aroma, mouthfeel and overall score.

\section{Microbiological evaluation.}

The following examinations were done for all formulas: Total bacterial count, (on standard plate count agar), Yeast and Mold were enumerated according to American Public Health Association Methods (APHA 1994). 


\section{Statistical analysis}

The obtained data from sensory evaluation and compositions were statistically analyzed by the Least Significant Differences value (LSD) at 0.05 levels probability according to the procedure of Mohan et al., (1985).

\section{RESULTS AND DISCUSSION}

\section{Physical properties of prepared formulas.}

Physical properties, such as $\mathrm{pH}$, water activity, viscosity and total soluble solids (TSS), for prepared formulas are illustrated in Table (2). There was a non-significant differences in $\mathrm{pH}$ value and water activity in all formulas, it ranged from 6.24 to 6.35 and 0.911 to 0.922 , respectively. There was a significant difference in viscosity and total solid among the tested samples, the highest values were found in formulae No 3, followed by formula No 2, while the lowest values were observed in formala No 1 .

Table 2. Physical characteristics of prepared formulas.

\begin{tabular}{|c|c|c|c|}
\hline Parameter & Formulae 1 & Formulae 2 & Formulae 3 \\
\hline $\mathrm{PH}$ & $6.35^{\mathrm{a}} \pm 0.03$ & $6.24^{\mathrm{a}} \pm 0.07$ & $6.81^{\mathrm{a}} \pm 0.09$ \\
\hline $\mathrm{a}_{\mathrm{w}}$ & $0.920^{\mathrm{a}} \pm 0.02$ & $0.911^{\mathrm{a}} \pm 0.04$ & $0.922^{\mathrm{a}} \pm 0.01$ \\
\hline Viscosity(CP) & $102.72^{\mathrm{c}} \pm 0.01$ & $105.64^{\mathrm{b}} \pm 0.01$ & $106.17^{\mathrm{a}} \pm 0.32$ \\
\hline TSS & $35.71^{\mathrm{c}} \pm 0.47$ & $37.13^{\mathrm{b}} \pm 0.18$ & $40.49^{\mathrm{a}} \pm 0.07$ \\
\hline
\end{tabular}

Values are means of three replicates \pm SD. Values number in the same raw followed by the same letter are not significantly different at 0.05 level:

\section{Chemical composition of the prepared formulas.}

The three formulas in our study were chemically analyzed as shown in Table (3). It could be noticed that there were significant $(P<0.05)$ differences in nutritive value of different formulas. The protein content of the tested formulas ranged from 14.3 to $22.89 \%$. The highest value in formula No 2 , which represents $176.07 \%$ RDA of the protein digestibility of the tested formulas ranged between 76.46 and 93.62\% RDA. Abd El_Hady and Habiba (2003), mentioned that cooking the legume seeds at a high temperature increases the protein digestibility such legume seeds, possibly by increasing the solubility of the protein. Some other factors such as grain structure and cell wall components of the seed that can also affect the solubility and digestibility of protein in seed. Protein could reacts, also with non-protein components present in seed during processing and it possibly leads to increase digestibility rates. While formula No 3 had the highest value of fat, ash and fiber. The higher content of fiber may be due to the presence of high ratio of legumes in formula No3 and No 2. On the other hand, formula No 3 had the highest content of energy, which represents $65.13 \%$ of RDA. On the other hand, it was reported that the presence of fibers could 
be of some necessity for more efficient and normal peristaltic movements of the gastrointestinal tract. Motawi et al., (2011)

Table 3. Chemical composition as well as caloric valus and protein digestability $(\mathrm{g} / 100 \mathrm{~g})$ and $\%$ RDA of the prepared formulas

\begin{tabular}{|l|c|c|c|c|c|c|c|}
\hline & & \multicolumn{2}{|c|}{ Formule 1 } & Formule 2 & & Formule 3 & \\
\hline Components \% & RDA(g) & & \%RDA & & \%RDA & & \%RDA \\
\hline Moisture & - & $1.52^{\mathrm{b}} \pm 0.72$ & - & $1.6^{\mathrm{a}} \pm 0.22$ & - & $1.47^{\mathrm{b}} \pm 0.23$ & - \\
\hline Protein & 13 & $14.3^{\mathrm{c}} \pm 0.03$ & 110 & $22.89^{\mathrm{a}} \pm 0.43$ & 176.07 & $17.95^{\mathrm{b}} \pm 0.27$ & 138.07 \\
\hline Fat & - & $0.8^{\mathrm{c}} \pm 0.03$ & - & $1.05^{\mathrm{b}} \pm 0.02$ & - & $2.0^{\mathrm{a}} \pm 0.06$ & - \\
\hline Ash & - & $2.6^{\mathrm{a}} \pm 0.01$ & - & $2.40^{\mathrm{b}} \pm 0.01$ & - & $2.36^{\mathrm{b}} \pm 0.05$ & - \\
\hline Fiber & - & $4.5^{\mathrm{c}} \pm 0.03$ & - & $6.06^{\mathrm{b}} \pm 0.05$ & - & $7.7^{\mathrm{a}} \pm 0.01$ & - \\
\hline $\begin{array}{l}\text { Total } \\
\text { Carbohydrate }\end{array}$ & 130 & $76.8^{\mathrm{a}} \pm 0.12$ & 61.6 & $66.18^{\mathrm{c}} \pm 0.03$ & 50.90 & $70.69^{\mathrm{b}} \pm 0.02$ & 54.37 \\
\hline $\begin{array}{l}\text { Caloric( Kcal } \\
\text { per100g) }\end{array}$ & 572 & $369.52^{\mathrm{b}} \pm 0.04$ & 64.60 & $365.73^{\mathrm{c}} \pm 0.03$ & 63.93 & $372.56^{\mathrm{a}} \pm 0.32$ & 65.13 \\
\hline $\begin{array}{l}\text { Protein } \\
\text { digestibility\% }\end{array}$ & & 89.07 & & 93.62 & & 76.46 & \\
\hline
\end{tabular}

Values are means of three replicates \pm SD. Values number in the same raw followed by the same letter are not significantly different at 0.05 levels $* \%$ protein digestibility was determined on fresh weight

Results showed in Table (3) also that in vitro protein digestibility in formula 1 was $89.07 \%$ and formula 2 was (93.62\%) which may be due to the high amount of legumes. High fiber content in formuls 3 significantly decrease the protein digestibility than other formulas. These results are in agreement with Abd El-Hady and Habiba (2003).who reported that some other factors (such as grain structure and cell wall components of the seed) can affect the solubility and digestibility of protein in seed.

\section{Amino acids content of prepared formulas}

The quality and functioning of a protein primarily depends on the composition of its essential amino acids. Results in Table (4) show amino acid content, chemical score, PER and BV of three different formulas. Results indicated that leucine represented the highest value of amino acid in all formulas, followed by lysine and valine, while histidine represented the lowest value. Histidine represented the first limiting amino acid in formula (1) and (2), while isoleucine represented the first limiting amino acid in formula 3. Protein efficiency ratio (PER) and biological value (BV) of all formulas indicated that a slight difference in PER and BV of formula (1) and (2). On the other hand,formula (3) represent the lowest value . 
Table 4. Chemical Score (C.S) and its Amino acid contents of the prepared formulas $\mathrm{mg} / \mathrm{g}$ protein.

\begin{tabular}{|c|c|c|c|c|c|c|c|}
\hline $\begin{array}{l}\text { Amino acids } \mathrm{mg} / \mathrm{g} \\
\text { protein }\end{array}$ & $\begin{array}{c}\mathrm{F} 1 \\
\mathrm{Amou} \\
\mathrm{nt}\end{array}$ & $\mathrm{CS}$ & $\begin{array}{l}\mathrm{F} 2 \\
\text { Amou } \\
\text { nt }\end{array}$ & CS & $\begin{array}{l}\text { F3 } \\
\text { Amou } \\
\text { nt }\end{array}$ & CS & $\begin{array}{l}\text { WHO/FAO pattern(1991) } \\
\text { for } \\
\text { Preschool child } 2-5 \text { years } \\
\mathrm{g} / 100 \mathrm{~g}\end{array}$ \\
\hline \multicolumn{8}{|l|}{ Essential amino acid } \\
\hline Valine* & 3.60 & 1.03 & 3.37 & 0.96 & 3.65 & 1.04 & 3.5 \\
\hline Therionine* & 3.45 & 1.01 & 2.80 & 0.82 & 3.91 & 1.15 & 3.4 \\
\hline Isoleucine* & 1.47 & 0.53 & 2.99 & 1.06 & 1.45 & 0.52 & 2.8 \\
\hline Leucine* & 6.86 & 1.04 & 6.68 & 1.03 & 5.95 & 0.90 & 6.6 \\
\hline Tyrosine* & 2.46 & & 2.80 & & 2.75 & & \\
\hline Phenylanine* & 2.59 & & 2.58 & & 2.78 & & \\
\hline $\begin{array}{l}\text { Phenylanine*+ } \\
\text { Tyrosine }\end{array}$ & 5.05 & 0.80 & 5.38 & 0.85 & 5.53 & 0.88 & 6.3 \\
\hline Hisitidine* & 0.27 & 1.4 & 0.92 & 1.5 & 1.68 & 0.88 & 1.9 \\
\hline Lysine* & 4.39 & 0.76 & 5.41 & 0.93 & 5.38 & 0.93 & 5.8 \\
\hline $\begin{array}{l}\text { Cystine+* } \\
\text { Methionine* }\end{array}$ & 3.15 & 1.26 & 4.52 & 1.80 & 3.08 & 1.23 & 2.5 \\
\hline Cystine & 1.24 & & 1.32 & & 1.25 & & \\
\hline Methionine & 1.91 & & 3.2 & & 1.88 & & \\
\hline Tryptophan & -- & -- & -- & -- & --- & --- & 1.1 \\
\hline Total E. A. A. & 28.24 & & 32.07 & & 30.63 & & 32.8 \\
\hline PER & 3.45 & & 3.67 & & 3.36 & & \\
\hline BV & 86.22 & & 88.58 & & 85.28 & & \\
\hline
\end{tabular}

*Essential amino acids. Proportion of essential amino acid and total amino acids as calculated by WHO/ FAO $1991 *$ C.S is the an Chemical score *(PER is the protein efficiency ratio * (BV is the biological value 
Table 5. Minerals content $(\mathrm{mg} / 100 \mathrm{~g})$ of prepared formulas and RDA

\begin{tabular}{|l|r|r|r|r|r|r|r|}
\hline Minerals & \multicolumn{1}{|c|}{ RDA } & formula 1 & \%RDA & formulas 2 & \%RDA & formulas 3 & \%RDA \\
\hline $\mathrm{Fe}$ & 7 & $8.08^{\mathrm{c}} \pm 0.34$ & 100 & $10.9^{\mathrm{a}} \pm 0.05$ & 155.71 & $9.98^{\mathrm{b}} \pm 0.02$ & 142.57 \\
\hline $\mathrm{P}$ & 460 & $377^{\mathrm{c}} \pm 0.06$ & 81.95 & $400^{\mathrm{b}} \pm 0.12$ & 86.95 & $455^{\mathrm{a}} \pm 0.03$ & 98.91 \\
\hline $\mathrm{Ca}$ & 488 & $407.5^{\mathrm{a}} \pm 0.06$ & 83.5 & $325.5^{\mathrm{c}} \pm 0.03$ & 66.7 & $380^{\mathrm{b}} \pm 0.07$ & 76.00 \\
\hline $\mathrm{Zn}$ & 3 & $4.5^{\mathrm{c}} \pm 0.45$ & 152.3 & $2.52^{\mathrm{b}} \pm 0.05$ & 229.0 & $5.0^{\mathrm{a}} \pm 0.12$ & 266.6 \\
\hline
\end{tabular}

Values are means of three replicates \pm SD. Values number in the same raw followed by the same letter are not significantly different at 0.05 level.

Data in Table (5) revealed that there was significant difference in iron, zinc, Ca and phosphorous in all formula, the highest value of iron was in formula 2 (10.9 $\mathrm{mg} / 100 \mathrm{~g}$ ). while formula 3 had highest $\mathrm{Zn}$ content. The variation in the minerals content in all formulas are due to the different content of these elements in the raw ingredients. From the results of minerals, it that the formulas were obvious represent a good source for some minerals.

Results in Table (6) indicated the bioavailability of iron, zinc and calcium in all formulas. Bioavailability of iron, zinc and calcium were ranged from 9.81 to $12.0,17.7$ to 10.7 and 4.98 to $30.65 \%$, respectively. It could be noticed that formula 3 had the highest bioavailability of zinc and calcium. The present results are confirmed by Hooda and Jood (2003) who demonstrated that fermentation and soaking process improved the availability of $\mathrm{Ca}, \mathrm{Fe}$ and $\mathrm{Zn}$. Phytic acid in plant foods forms complexes with essential dietary minerals such as $\mathrm{Ca}, \mathrm{Fe}, \mathrm{Zn}$ and $\mathrm{mg}$ makes them biologically unavailable for absorption.

Table 6. Fe, $\mathrm{Zn}$ and $\mathrm{Ca}$ in vitro Bioavailability of the formulas $(\mathrm{mg} / \mathrm{100 \textrm {g }}$ ).

\begin{tabular}{|c|c|c|c|c|c|c|c|c|c|}
\hline Minerals & \multicolumn{3}{|c|}{$\mathrm{Fe}$} & \multicolumn{3}{|c|}{$\mathrm{Zn}$} & \multicolumn{3}{|c|}{$\mathrm{Ca}$} \\
\hline & \multirow{2}{*}{$\begin{array}{c}\text { Total } \\
\text { mg }\end{array}$} & \multicolumn{2}{|c|}{ Bioavailability } & \multirow{2}{*}{$\begin{array}{l}\text { Total } \\
\text { mg }\end{array}$} & \multicolumn{2}{|c|}{ Bioavailability } & \multirow{2}{*}{$\begin{array}{c}\text { Total } \\
\text { mg }\end{array}$} & \multicolumn{2}{|c|}{ Bioavailability } \\
\hline & & $\mathrm{Mg}$ & $\%$ & & $\mathrm{mg}$ & $\%$ & & $\mathrm{Mg}$ & $\%$ \\
\hline Formula 1 & $8.08^{c}$ & $0.97^{b}$ & $12.0^{\mathrm{a}}$ & $4.5^{c}$ & $0.811^{\mathrm{b}}$ & $17.7^{\mathrm{a}}$ & $488^{c}$ & $23.871^{c}$ & $4.89^{c}$ \\
\hline Formula 2 & $10.9^{a}$ & $1.07^{\mathrm{a}}$ & $9.81^{\mathrm{b}}$ & $7.5^{\mathrm{b}}$ & $0.808^{b}$ & $10.7^{c}$ & $325^{a}$ & $71.517^{b}$ & $22.0^{\mathrm{b}}$ \\
\hline Formula 3 & $9.98^{b}$ & $0.99^{b}$ & $9.91^{\mathrm{b}}$ & $8.0^{\mathrm{a}}$ & $1.295^{\mathrm{a}}$ & $16.2^{\mathrm{b}}$ & $280^{b}$ & $85.844^{a}$ & $30.65^{a}$ \\
\hline
\end{tabular}

* Each value in the same column followed by the same letter are not significantly different at $(p \leq 0.05)$.

Sensory evaluation of the formulas is one of the important tests to determine their acceptability. Table (7) illustrated the mean values of sensory characteristics scores such as texture, color, taste, aroma, mouthfeel and the overall average scores 
of the prepared formulas at zero time and after 15 days. These result agree with Duxburg (2005). The obtained results indicated that there was a significant difference in all sensory parameters among the three formulas except color and mouth feel parameter in formula ( 1) and (3). The highest overall scores are exhibited by formula (1) followed by formula (2). The same trend of sensory evaluation of the three formulas was found after the 15 days of storage.

Table 7. Sensory evaluation of prepared formula at zero time and after 15 days

\begin{tabular}{|l|c|c|c|c|c|c|}
\hline & \multicolumn{3}{|c|}{ Zero time } & \multicolumn{3}{c|}{15 days } \\
\hline & F1 & F2 & F3 & F1 & F2 & F3 \\
\hline Texture & $9.1^{\mathrm{a}} \pm 1.19$ & $7.75^{\mathrm{b}} \pm 1.10$ & $7.8^{\mathrm{b}} \pm 0.91$ & $9.0^{\mathrm{a}} \pm 1.17$ & $7.8^{\mathrm{b}} \pm 0.98$ & $7.7^{\mathrm{b}} \pm 0.86$ \\
\hline Color & $8.9^{\mathrm{a}} \pm 0.99$ & $8.45^{\mathrm{b}} \pm 0.83$ & $8.9^{\mathrm{a}} \pm 0.86$ & $8.9^{\mathrm{a}} \pm 1.18$ & $8.4^{\mathrm{b}} \pm 0.83 \mathrm{~b}$ & $8.9^{\mathrm{a}} \pm 1.19$ \\
\hline Taste & $9.1^{\mathrm{a}} \pm 0.99$ & $8.95 \pm 0.74$ & $8.9^{\mathrm{c}} \pm 0.99$ & $9.0^{\mathrm{a}} \pm 0.87$ & $8.0^{\mathrm{b}} \pm 1.18 \mathrm{~b}$ & $7.9^{\mathrm{c}} \pm 0.99$ \\
\hline Aroma & $8.9^{\mathrm{a}} \pm 1.10$ & $8.2^{\mathrm{b}} \pm 1.032$ & $8.3^{\mathrm{b}} \pm 1.08$ & $8.5^{\mathrm{a}} \pm 0.089$ & $8.2^{\mathrm{b}} \pm 1.03 \mathrm{~b}$ & $8.0^{\mathrm{b}} \pm 1.10$ \\
\hline Mouth feel & $8.7^{\mathrm{a}} \pm 1.23$ & $8.2^{\mathrm{b}} \pm 0.918$ & $8.7^{\mathrm{a}} \pm 1.25$ & $8.5^{\mathrm{a}} \pm 0.98$ & $8.0^{\mathrm{b}} \pm 1.16 \mathrm{~b}$ & $8.5^{\mathrm{a}} \pm 1.14$ \\
\hline Overall & $9.4^{\mathrm{a}} \pm 0.98$ & $9.0^{\mathrm{b}} \pm 0.96$ & $8.9^{\mathrm{c}} \pm 1.05$ & $9.0^{\mathrm{a}} \pm 0.89$ & $8.8^{\mathrm{b}} \pm 0.89$ & $8.5^{\mathrm{b}} \pm 0.56$ \\
\hline
\end{tabular}

Values represent Mean of 10 panelists \pm SE. * a, b Values number in the same raw followed by the same letter are not significantly different at 0.05 level.

The total microbial count of the prepared formulas in Table (8) reveled that, TBC $(\mathrm{cfu} / \mathrm{g})$, were not detected at zero time, and after7 days no growth, while TPC were $1 \times 10^{2}$ CFU /g after 15 days there were days of storage at refrigerator at $5{ }^{\circ} \mathrm{C}$ of three formulas. Yeast and mould were not detected at zero time or after storage. This is may be due to boilied process, good quality of raw materials.

Table 8. Examination quality of the prepared formulas (CFU/g)

\begin{tabular}{|l|c|c|c|c|r|r|r|r|r|}
\hline & \multicolumn{2}{|c|}{$\begin{array}{c}\text { Zero } \\
\text { time }\end{array}$} & \multicolumn{2}{c|}{ 7days } & \multicolumn{2}{|c|}{15 day } \\
\hline Formula & F1 & F2 & F3 & F1 & F2 & F3 & F1 & F2 & F3 \\
\hline TBC & - & - & - & - & - & - & $1 \times 10^{2}$ & $1 \times 10^{2}$ & $2 \times 10^{2}$ \\
\hline $\begin{array}{l}\text { Yeast and } \\
\text { molud }\end{array}$ & ND & ND & ND & ND & ND & ND & ND & ND & ND \\
\hline
\end{tabular}

(TBC) Total bacterial count.

ND: no defect

\section{CONCLUSION}

In conclusion, this study show that it could be prepared good nutritional formulas for children (1-3 years) from local materials and low price in home or as commercial products. Also it could be used as a composite diets for children who suffering from malnutrition. The formulas prepared in the present study can be successfully used in under weight, over weight and normal children. Sensory evaluation indicated that there were significant differences $(p<0.05)$ among the three composite diets in texture, taste and overall acceptability before and after storage and diet (1) was the 
best compared other formulas. Furthermore, indicating the absence of contamination of the composite samples.

\section{REFERENCES}

1. AOAC. 2012. Official Methods of Analysis of the Association of Official Analytical Chemists, $19^{\text {th }}$ ed , Arligton, Virginia,USA.

2. Abd El-Hady, E.A. and Habiba, R.A. 2003. Effect of soaking and extrusion conditions on antinutrients and protein digestibility of legume seeds. LWT-Food Sci. Technol., 36: 285-293

3. Akeson, W. R. and Stahmann, M. A. 1986. Pepsin pancreatin digest index of protein quality evaluation. J. Nutr., 83: 257-261.

4. Aleid, S. M. 2006. Chromatographic separation of fructose from date syrup. Int J Food Sci . Nutr. , 57:83-96.

5. Al-Farsi, M.A and Lee, C.Y. 2008. Nutritional and functional properties of dates: a Review. Crit. Rev. Food. Sci. Nutr., 48:877-87

6. ALsmeyer, R. H; Cunning, A. E. and Happich, M.L.1974. Equations predict PER from amino acid analysis. Food Technology.28(7):34-40.

7. APHA. 1994. Standard methods for the examination of dairy products, $16^{\text {th }} \mathrm{Ed}$, American Public Health Association, Washington, USA.

8. D'Souza, M. R .2013. Effect of traditional processing methods on nutritional quality of field bean. Adv. Biores ,4(3):29-33.

9. Duxbury, D. 2005. Sensory evaluation provides value Food Technology,(5):59-68.

10. El-Mougi, M. 2016. Nutrition (Basic Pediatrics $5^{\text {th }}$ edition, El Fagr centre press, Cairo, Egypt. Chapter7.p.111-157.

11. FAO/WHO 1991. Protein quality Evaluation Reports of a joint FAO/WHO expert Consultation, Food and Agriculture Organzation of the United Nations, FAO,Rome.

12. Hooda, S. and Jood, S. 2003. Effect of soaking and germination on nutrient and antinutrient contents of fenugreek (Triwnella Foenum Graecum L.). J. Food biochemist., 27:165-176.

13. Kiers, J .L ; Nout, M. J; and Rombouts, F.M. 2000. Invitro digestibility of processed and fermented soya bean,cowpea and maize. J. Sci. Food Agric., 80:1325-1331.

14. Kittiphoom, S. 2012. Chemical and technological studies on production of mango nectar .International Food Research Journal 19(4): 1325-1335 (2012)..

15. Metwalli, O.M.; Al-Okbi, S. Y. and Hamed, T. E. 2011. Chemical, biological and organoleptic evaluation of newly formulated therapeutic diets for protein calorie malnutrition. Med. J. Islamic World Acad. Sci.,19 (2):67-74 . 
16. Mohan, R.; Kathleen, B. and Marc ,Z.1985. PC-STAT, Version1A(One Way Analysis of Variance), University of Georgia, USA.

17. Motawi, K.T.; Hamed, A. M.;Shabana, H. M.;Hahem, M.R and Aboul N, F.A(2011). Zingiber officinale acts as a nutraceutical agent against liver fibrosis Nutrition and Metabolism,8:40.

18. Oser, B .L.1959. An integrated essential amino acid index for predicting the biological value of protein. The Protein and Amino Acid Nutritionrd. Ibanese, A.A.A.by Academic Press, New York

19. Pastor, M.V.; Costell, E. and Duran, L.1996. Effect of hydrocolloids and aspartame on sensory viscosity and sweetness of low calorie calorie peach nectars. J.Texture Stud.,27:61-78

20. Tarzi BG; Gharachorloo M; Baharinia M and Mortazavi S A. 2012.The effect of germination on phenolic content and antioxidant activity of chickpea Iranian J. Pharmaceutical Res.,11(4) : 1137-1143. 


\title{
اعداد وتقييم خلطات غذائيه مختلفه لتغذيه الاطفال (سن ا-r سنوات)
}

\author{
اميمه محمد دويدار' -ايات ابر اهيم رزق ' - محمد حسن احدّ" \\ ا ـ قسم بحوث تكنولوحيا الدحاصيل - معرد بحوث تكنولوجيا- مركز البحوث الزراعيه \\ r ـ قسم الاغذيه الخاصه و التغذيه - معرج بحوث تكنولوجيا- مركز البحوث الزرراعبه

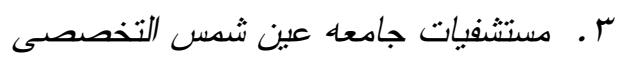

التغذية السليمة في السنوات الاولي من العمر جزء اساسي لصحة الاطفال. لذا تم تحضير

ثلاث خلطات غذائية للاطفال من(سن ا-r سنوات) من كل من مسلوق الارز و القمح و الذره

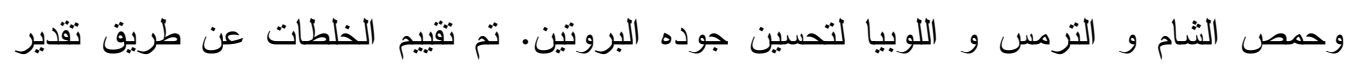

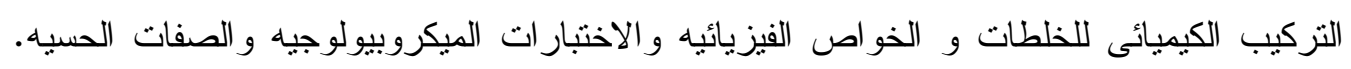

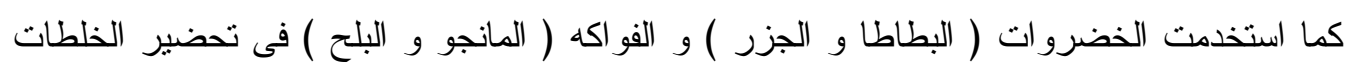

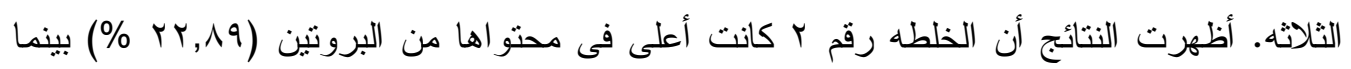

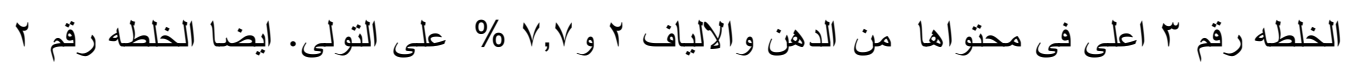

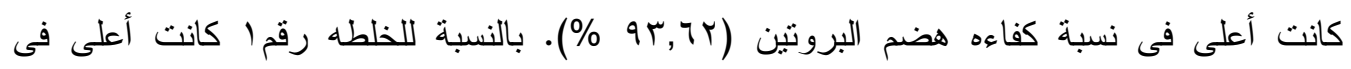

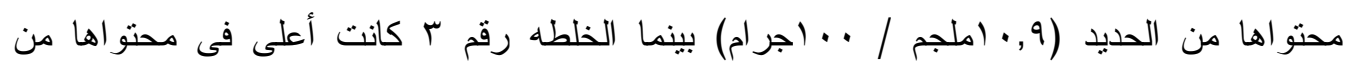

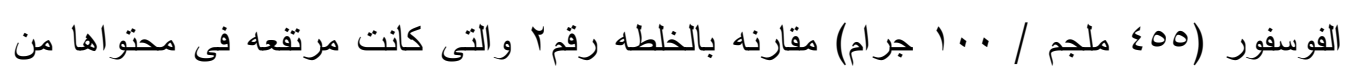

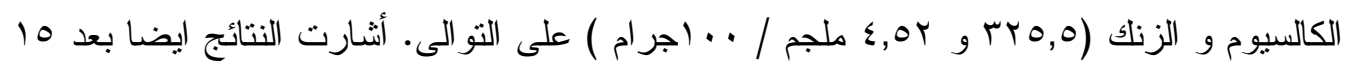

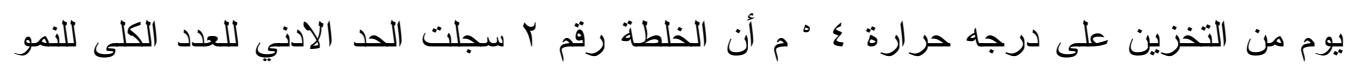

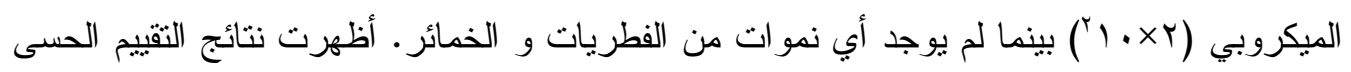

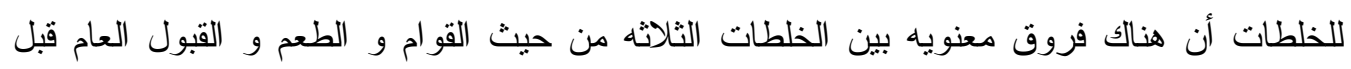

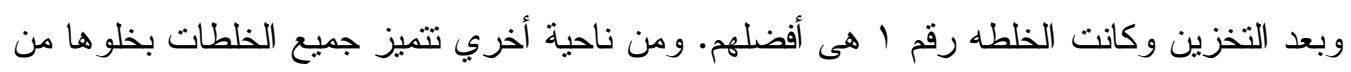

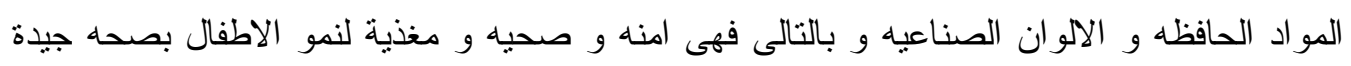

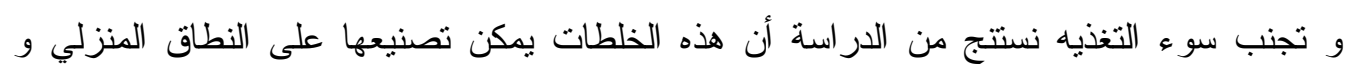
كذلك على النطاق التجاري. 